\title{
¿Quién te ha condenado? La mujer adúltera: justicia y misericordia*
}

\author{
Hernán Sevillano Castillo**
}

Recibido: 26 de octubre de 2017 • Aprobado: 30 de noviembre de 2017

\section{Resumen}

A lo largo de la historia la mujer ha sido discriminada por múltiples razones. En lo político, lo social y lo religioso, su papel ha sido poco relevante. El pasaje de la mujer adúltera del Evangelio de Juan (Jn 7,53-8,11), deja en evidencia el trato de Jesús con las mujeres. Es un trato exquisito hacia ellas. Revolucionario en sus palabras y acciones, Jesús devuelve a la mujer el estado de igualdad recibido por Dios en la creación (Gn 1,26). Demostrando que Dios siempre es justo y misericordioso con los débiles, y excluidos. La presencia de Jesús en el relato resulta alentadora, restaurativa y misericordiosa para la mujer aplicando el principio de "misericordia quiero y no sacrificio".

Palabras clave: mujer, misericordia, justicia, ley.

* Este artículo es una exegesis, sobre la perícopa de la mujer adúltera. DOI: http://dx.doi. org/10.15332/s2011-9771.2017.0002.06

* Licencia sacra en Teología y Magíster en Teología de la Pontificia Universidad Javeriana. Bogotá. Sacerdote de la Orden de los Carmelitas Descalzos. Correo electrónico: dilsonocd@ gmail.com 


\title{
Who has condemned you? The adulterous woman: justice and mercy
}

\begin{abstract}
Throughout history, women have been discriminated for multiple reasons. Politically, socially and religiously, her role has been little relevant. The passage of the adulterous woman in John's Gospel (John 7, 53-8,11), reveals the treatment of Jesus with women. It is an exquisite treatment towards them. Revolutionary in his words and actions, Jesus returns to women the state of equality received by God in the creation (Gen. 1, 26). Proving that God is always just and merciful to the weak, and excluded. The presence of Jesus in the story is encouraging, restorative and merciful for the woman applying the principle of "I desire mercy, not sacrifice" .
\end{abstract}

Keywords: woman, mercy, justice, law.

\section{Quem te tem condenado? A mulher adultera: justiça e misericórdia}

\section{Resumo}

Ao longo da história a mulher tem sido discriminada por múltiplas razões. No âmbito político, social e religioso seu papel tem sido pouco relevante. A passagem da mulher adultera no evangelho de João (João 7,53-8,11) evidencia o trato de Jesus com as mulheres. É um trato requintado para elas; revolucionário em suas palavras e ações, Jesus desenvolve a mulher o estado de igualdade recebido por Deus na criação (Gênesis 1,26). Demonstrando que Deus sempre é justo e misericordioso com os fracos e excluídos. A presença de Jesus no relato é alentadora, restaurativa e misericordiosa para a mulher, aplicando o princípio de "misericórdia quero e não sacrifício".

Palavras-chave: mulher, misericórdia, justiça, lei. 


\section{Introducción}

A lo largo de la historia la mujer ha sido discriminada por múltiples razones. En la religión, su papel ha sido poco relevante. Políticamente sus derechos como mujer fueron limitados, vinculados al horizonte cultural dominado por los hombres. La mujer durante mucho tiempo sin vida pública, fue relegada a oficios domésticos donde actuaba como sirvienta y propiedad del marido. No es difícil reconocer que la mujer durante décadas estuvo marginada social, política y religiosamente. Por ejemplo, llama la atención un texto escrito por santa Teresa de Jesús en pleno siglo XVI, donde suplica y expone a Jesús la situación de la mujer en su época. Dice santa Teresa:

Yo confío, Señor mío, en estas siervas vuestras que aquí están, que como veo y sé, no quieren otra cosa que contentaros; por Vos han dejado lo poco que tenían, y quisieran tener más para serviros con ello. Pues no sois Vos, criador mío, desagradecido para que piense yo daréis menos de lo que os suplican, sino mucho más. Ni aborrecisteis, Señor de mi alma, cuando andabais por el mundo, las mujeres, antes las favorecisteis siempre con mucha piedad y hallasteis en ellas tanto amor y más fe que en los hombres... ¿No basta, Señor, que nos tiene el mundo acorraladas e incapaces para que no hagamos cosa que valga nada por Vos en público, ni osemos hablar algunas verdades que lloramos en secreto, sino que no nos habíais de oír petición tan justa? No lo creo yo, Señor, de vuestra bondad y justicia, que sois justo juez, y no como los jueces del mundo, que como son hijos de Adán $\mathrm{y}$, en fin, todos varones, no hay virtud de mujer que no tengan por sospechosa (Santa Teresa de Jesús, 2000, p. 521).

Esta situación se ha extendido hasta nuestros días en algunos sectores de la sociedad.

Ahora bien, con la perícopa de la mujer adúltera (Jn 7,53-8,11), queremos abordar mediante un estudio exegético la manera como Jesús se relacionaba con las mujeres. Jesús bíblicamente hablando, expresa un trato exquisito hacia ellas; revolucionario en sus palabras y acciones, devuelve a la mujer el estado de igualdad recibido por Dios en la creación (Gn 1,26). En la perícopa, se nos presenta a una mujer en riesgo. Sus acusadores amparados en la ley de Moisés quieren lapidarla. La presencia de Jesús en el relato resulta alentadora, restaurativa y misericordiosa. No obstante, la presencia de Jesús es fruto de una conspiración que da un desenlace distinto al relato. Sin embargo, abre camino para dejar entrever la misericordia Divina con quienes se encuentran en situación de vulnerabilidad. 
El presente trabajo exegético se desarrollará en cinco partes: 1) la autenticidad de la perícopa acorde con los principios propios de la crítica textual, 2) criterios sobre los que se establece la estructura del texto, 3) una aproximación exegética del texto de acuerdo al método sincrónico, análisis literario y narrativo, 4) Presentar algunos elementos teológicos extraídos del texto y, 5) concluir con un análisis hermenéutico del texto mirando la parte jurídica ${ }^{1}$.

\section{La autenticidad de la perícopa: crítica textual}

La autenticidad de esta perícopa ha sido cuestionada desde siempre. Hoy con certeza se afirma que no pertenece al corpus joánico, sino que es añadida posteriormente. Se desconocen las razones. La crítica textual nos dará elementos para saber abordar y conocer los resultados de este texto en el Evangelio de Juan.

\subsection{Texto narrativo}

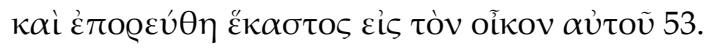

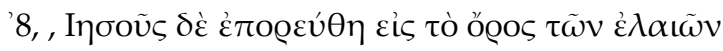

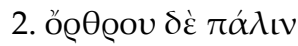

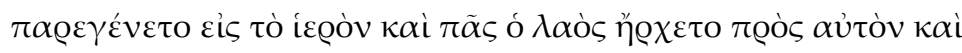

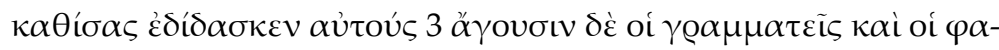

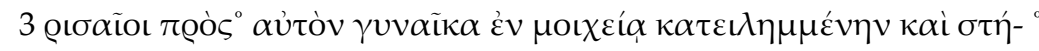

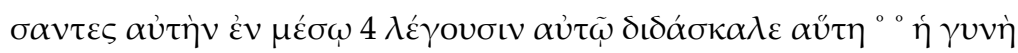

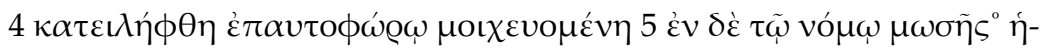

1 En este análisis dejaremos de lado, la organización de las palabras en su orden de importancia, las oraciones de sentidos y el análisis de las palabras independientes y dependientes. 


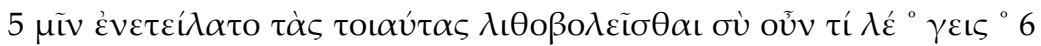

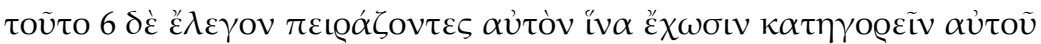
ó $\delta \dot{\varepsilon}$ ì - $^{\circ}$

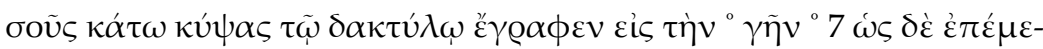

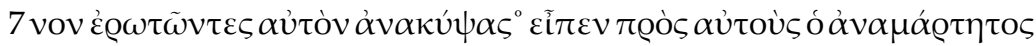

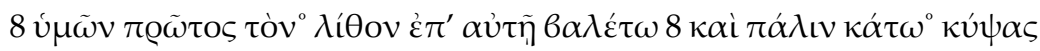

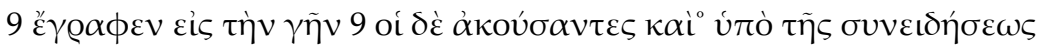

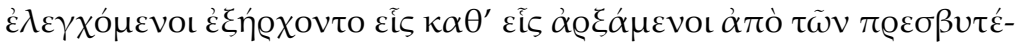

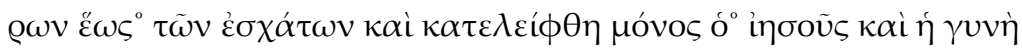

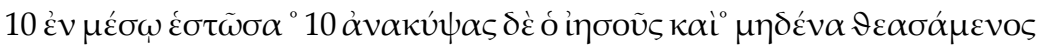

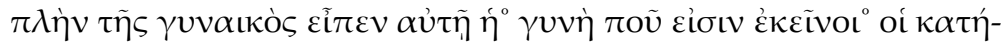

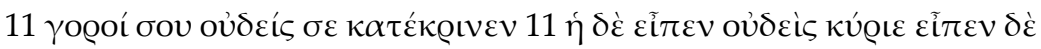

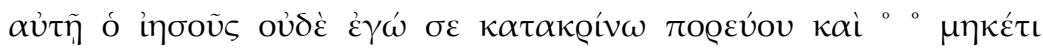
$\dot{\alpha} \mu \alpha \dot{\rho} \alpha \tau \nu \varepsilon$.

\subsection{1. ¿De qué tipo de texto se trata?}

En la perícopa de la mujer adúltera encontramos un texto de carácter narrativo. Se puede distinguir que es una narración debido a que se destacan los dos elementos principales del género literario: narrador y trama.

a. El narrador: en la perícopa una voz está narrando la historia, asume la voz del pueblo y a su vez, cede la palabra a los personajes: Incorporándose Jesús le dijo: "Mujer, ¿dónde están? ¿Nadie te ha condenado?" $(8,10) \ldots$ Ella respondió: “Nadie, Señor.” (11.a). El narrador describe y comenta los acontecimientos que ocurren dentro de la historia: Jesús que sube al monte, (1), le llevan a una mujer (3).

b. La trama: gira en torno a la acusación de una mujer sorprendida en adulterio. Jesús es abordado como Maestro que debe dar el veredicto, solucionar el impase. Jesús asume el papel de Juez asignado por los 
acusadores. Los acusadores (1) le presentan a Jesús el hecho (v.4); (2) le recuerdan la norma de la Ley: “Moisés nos mandó en la Ley apedrear a estas mujeres" (v.5a; note que se omite la referencia al varón); (3) le piden el veredicto: “¿Tú que dices?” (v.5b) (Oñoro, 2004, p. 3)

\subsection{2. ¿Cuál es la acción principal?}

El evangelista nos dice que "esto lo decían para tentarle, para tener de qué acusarle" (v.6 $\left.6^{\text {a }}\right)$. Oportuna precisión que saca a la luz la cuestión de fondo: 1) Si Jesús aprueba el comportamiento de sus enemigos, también acepta su posición contra los pecadores; en consecuencia, tendría que ponerle fin a su praxis de misericordia y aparecer ante el pueblo como un falso maestro. 2) Pero si Jesús no lo hace, resulta que termina desaprobando una ley inequívoca ante un hecho inequívoco, e igualmente daría motivos para ser acusado de falso maestro que aparta a la gente de la Ley de Dios y, en consecuencia, debería ser quitado de en medio del pueblo (Oñoro, 2004, p. 3).

\subsection{Originalidad de la perícopa: variante textual}

Como ya hemos mencionado, para algunos este pasaje no es de Juan. Obedece más a un añadido, aunque para otros debe ser reconocido como un texto joánico. Solo las variantes textuales, dos, darán una pauta sobre el origen de este relato.

\subsection{1. ¿Por qué la perícopa comienza en este versículo y no en el anterior o siguiente?}

Siguiendo las líneas de Schnackenburg, el relato supone la presencia de Jesús en el templo. Ha terminado el sermón, y según indicaciones cronológicas, el escenario ha cambiado. Los oyentes se devuelven a su casa, lo cual supone una conclusión con respecto del discurso anterior $(7,53)$. Jesús sube al monte $(8,1)$ lo cual se debe interpretar como una acción de despedida. Como ya se ha anotado, tiene una conclusión explicita que anuncia el término del diálogo: “y volvieron cada uno a su casa $(7,53)$ (Schnackenburg, 1980, p. 227).

El nuevo relato comienza con una introducción en donde la escena se reanuda en la madrugada, en el templo con la presencia de todo el pueblo $(8,2)$. La escena incluye la presencia de Jesús, los escribas y fariseos, la mujer y los del pueblo. Entre el vocabulario característico se pueden destacar: escribas, y fariseos, 
adulterio. Entre las indicaciones geográficas, el relato muestra una ubicación en "el Monte de los Olivos en hebreo: סיתיזה רה, ubicado en el valle de Kidrón. Como lugar geográfico también indica el Templo de Jerusalén (שדקמה תיב, Beit Hamikdash)" (Sed-Rajna, 2000, p. 116).

En aquello que se refiere a indicaciones cronológicas resalta el relato, la madrugada como tiempo de transición del nuevo día, lo que deja en evidencia que la escena se desarrolla en horas de la mañana y de día. Cabe inferir que el relato no da pie a detalles, se puede suponer la "especulación de los días de la fiesta de los tabernáculos con su alegría desenfrenada, eran días especiales para tales deslices" (Schnackenburg, 1980, p. 227).

Indudablemente se puede constatar que la perícopa no es original del Evangelio joánico: este pasaje que interrumpe el de los tabernáculos, varios papiros omiten su presencia, razón por la cual no presenta palabras o pasajes puentes con el discurso siguiente del Evangelio, limitando así su definición como perícopa que comienza y termina puntualmente. Sin embargo, su ubicación, en la parte anterior a la perícopa se entronca en el discurso sobre las tiendas $(7,1-52)$ y posteriormente desde $(8,12-59)$.

\subsection{Variantes textuales}

Como ya hemos afirmado, la gran mayoría de los autores dan fe de que esta perícopa forma parte del corpus joánico en sus escritos. En el comentario bíblico de san Jerónimo, se puede leer: "originariamente no formaba parte del Evangelio de Juan. Lo omiten P 66 y P 7 y todos los códigos mayores, excepto D (Brown, Fitzmayer y Murfhy, 1972, p. 446):

Los testigos griegos más antiguos del texto del cuarto Evangelio no conocen la perícopa de la mujer adúltera (P 66,75 B L N T W X Y 01410211 22331241572097888281230124112421253 2193) sino que leyeron un texto que $(\mathrm{Jn} 7,52)$ pasa inmediatamente a $(8,11)$. En realidad, el código más antiguo que contiene la perícopa es el Bezae Cantabrigensis del siglo V (Sánchez, 2010, p. 18).

En el comentario textual se añade que los códices A y C se hayan incompletos y con probabilidad de que ninguno de los dos haya contenido la perícopa. De igual forma, los manuscritos armenios y las traducciones siriacas no la registran. Los Padres griegos la omiten, solo aparece en la traducción vulgata y la ventus latina (Metzger, 2006, pp. 187-188). 
No obstante, el texto está bien atestiguado por los Padres latinos, por lo cual no se pone en duda su carácter inspirado y la autenticidad histórica. Quizá el motivo de controversia seguirá siendo su autor, según indica Sánchez (2010) cuando afirma que:

Es necesario señalar que hay manuscritos en los que la perícopa en mención se encuentra en otros lugares. Así, por ejemplo, el manuscrito minúsculo 225 presenta el episodio después de Jn 7,36, mientras que en los manuscritos de la familia 1 ( 11 ) se encuentra al final del cuarto Evangelio (Jn 21,25). También se encuentra en el tercer Evangelio, o antes del relato de la pasión (Lc 21,38), como en los manuscritos de la familia 13 (f13), o al final de todo el Evangelio (Lc 24,53), como en el manuscrito 1333c. Las diversas evidencias textuales muestran cómo la economicidad de la perícopa fue reconocida después de un largo proceso, que fue más rápido en Occidente que en Oriente. A este respecto la tradición latina de la perícopa es anterior a la Vulgata de san Jerónimo. Es importante tener en cuenta que el episodio de la mujer adúltera es la sección del Nuevo Testamento que presenta más variables textuales, esto permite percibir una historia llena de cambios en los primeros tiempos de su pertenencia al canon (p. 20).

Por otro lado, Metzger, señala que en algunos manuscritos existe omisión de palabras como a continuación se indican:

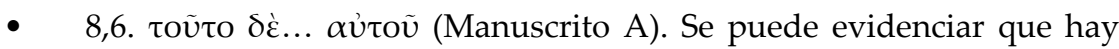
manuscritos que omiten estas palabras y las introducen después del versículo 4, (D 1071) o aparecen después del 11 (M).

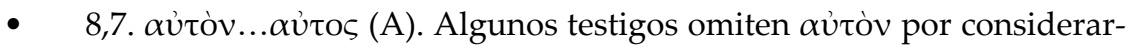
lo superficial, mientras que otros sustituyen $\alpha \dot{\tau} \tau o i \varsigma$ con la frase prepo-

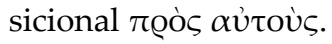

- $\quad$ 8,8. $\gamma \tilde{\eta} v$. Este artículo aparece como una curiosidad de saber qué escribió Jesús en el suelo, de ahí que en algunos manuscritos añadan la frase: enos ekáston antwo tas amartia (los pecados de cada uno de ellos) (U II 73 3313647007821592 arm, mms).

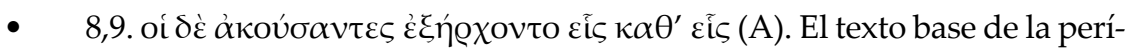
copa añade glosas explicativas, por su parte el Textus Receptus añade que los acusadores mismos de la mujer eran reprobados por su consciencia.

- $\quad$ 8.10. ìnooũs (A). Se presenta un detalle de la mirada de Jesús sobre la mujer. 
- $\quad$ 8,10, тoũ ciơv. En este caso Textus Receptus, sigue a EFGK 079 al, añadiendo: ekeinoi oi kateyoroí (“esos, los acusadores tuyos”) (Metzger, 2010, pp. 187-188).

En línea con lo que ya se ha mencionado, y de cara a la crítica textual, no se puede afirmar con absoluta seguridad que el lugar original de la perícopa haya sido el Evangelio de Juan o el de Lucas:

Es útil tener en cuenta que la evidencia más antigua de la existencia de la perícopa es Papías de Hierápolis, cuya autoridad se sustenta en el apelativo de. A él se refiere Eusebio de Cesarea cuando afirma: “Expuso también otra historia acerca de la mujer que fue acusada ante el Señor de muchos crímenes. Esa historia se encuentra escrita en el Evangelio de los Hebreos"(Historia Eclesiástica III, 39,17) (Sánchez, 2010 p. 21).

Ahora bien, de acuerdo al testimonio de Dídimo de Alejandría, a finales del siglo VI, esa perícopa existía en algunos evangelios. El testimonio de Papías, de la Didaskalia, de Rufin, del protoevangelio de Santiago, de Orígenes y de algunos manuscritos griegos del siglo XI, deja entrever que la perícopa proviene de un ambiente judeo-cristiano, desde donde pasó al Evangelio. Cabe resaltar que la perícopa, ha ocupado varios sitios dentro del Evangelio juanista. Así lo corroboran varios manuscritos. Por ejemplo, el manuscrito 225 la ubica después de Jn 7,36 , en $f 1$, la encontramos en Jn 21,25. De igual manera se encuentra en el Evangelio de Lucas, 21,38; 2453, manuscrito f13, y 1333 (Sánchez, 2010, p. 20).

En alguna medida se puede intuir que la perícopa y la vida de Jesús están relacionadas. La pregunta en torno a la cual gira la discusión, era frecuente en el judaísmo en la época de Jesús: la pregunta abre el debate sobre la validez y la aplicabilidad de la ley (Lv 20,10 y Dt 22,22). Ante esta trampa tendida, Jesús, en contra de la Torá y sus representantes, toma partido por la mujer y decide perdonarla sin condiciones.

Finalmente, la pregunta se mantiene: ¿siendo un relato tan antiguo por qué no entró en el canon directamente o en su defecto del evangelio de Juan desde sus inicios? Las respuestas al respecto son variadas. Una de las causas posibles que plantea $R$. Brown, citando a Riesenfeld, tiene que ver con la facilidad con que Jesús perdona la infidelidad, postura difícil de conciliar con la dura penitencia de las primeras comunidades cristianas, hasta que no se puso una disciplina penitencial no se aceptó ampliamente el relato (Brown, 2010, p. 570). Sin embargo, se puede afirmar que el relato es de origen oriental y muy antiguo. 


\section{La estructura del texto}

Como ya se ha hecho mención, es importante ubicar la perícopa dentro de su contexto más amplio, ¿cuál es su significado dentro del espacio en que se encuentra o qué modificaciones ocasiona? La ubicación la podemos resumir de la siguiente forma:

a. La perícopa (Jn 7,53-8,1-11) se enmarca dentro de la fiesta litúrgica de los judíos, la fiesta de las tiendas en Jerusalén $(7,1-10,21)$.

b. Hay una fuerte tensión entre los judíos y Jesús, al punto que le buscan para matarle $(7,1)$.

c. El envío de Jesús a sus hermanos a Jerusalén $(7,8)$.

d. Jesús llega en secreto a participar de las fiestas (710).

e. Se presenta en público a enseñar en presencia del pueblo $(8,1)$.

f. Jesús se oculta porque va a ser lapidado $(8,59)$.

Ahora bien, siguiendo los comentarios que recoge Sarasa, sobre el punto específico de la ubicación de la perícopa, el texto se puede considerar como parte de la unidad, dejando de lado, como ya se hizo mención, su autenticidad y canonicidad. Ante todo se pretende descubrir el sentido de por qué la perícopa está en ese preciso lugar:

Ella, la perícopa, ayuda en su aspecto narrativo a dar un soporte visual sobre la discusión de en cuanto a la relación de la ley y el pecado, sobre el mal y el juicio moral. Ayuda a no permanecer en consideraciones abstractas y teóricas. Tal vez sea la razón de su ubicación: Jesús que entra en el templo $(8,2)$, la acción de la lapidación $(8,7)$ en relación al relato posterior $(8,59)$ que habla de lapidar a Jesús, que luego sale del templo. Resulta sorprendente que en ninguno de los casos la acción de condena se cumple, la primera contra la mujer. La segunda contra Jesús. Se da un contraste: Jesús que no condena, resulta condenado (Sarasa, 2005, p. 28).

Por otro lado, la unidad literaria del texto que logra percibirse mediante

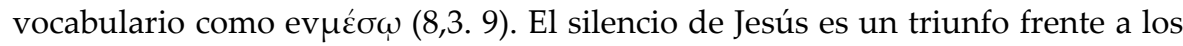
acusadores, cuya sentencia termina con la absolución de la mujer $(8,11)$. Por su parte, el esquema que plantea Sánchez, propone dos partes: 1) la introducción del narrador cuyo escenario es el templo de Jerusalén y, 2) la controversia $(8,3,11)$ subdivida en: a) la trampa a Jesús $\left(8,3-6^{\mathrm{a}}\right)$, b) escape de la trampa $(8,6 b-9)$ y, c) la sentencia de Jesús (8,10-11) (Sánchez, p. 2010, p. 28). 


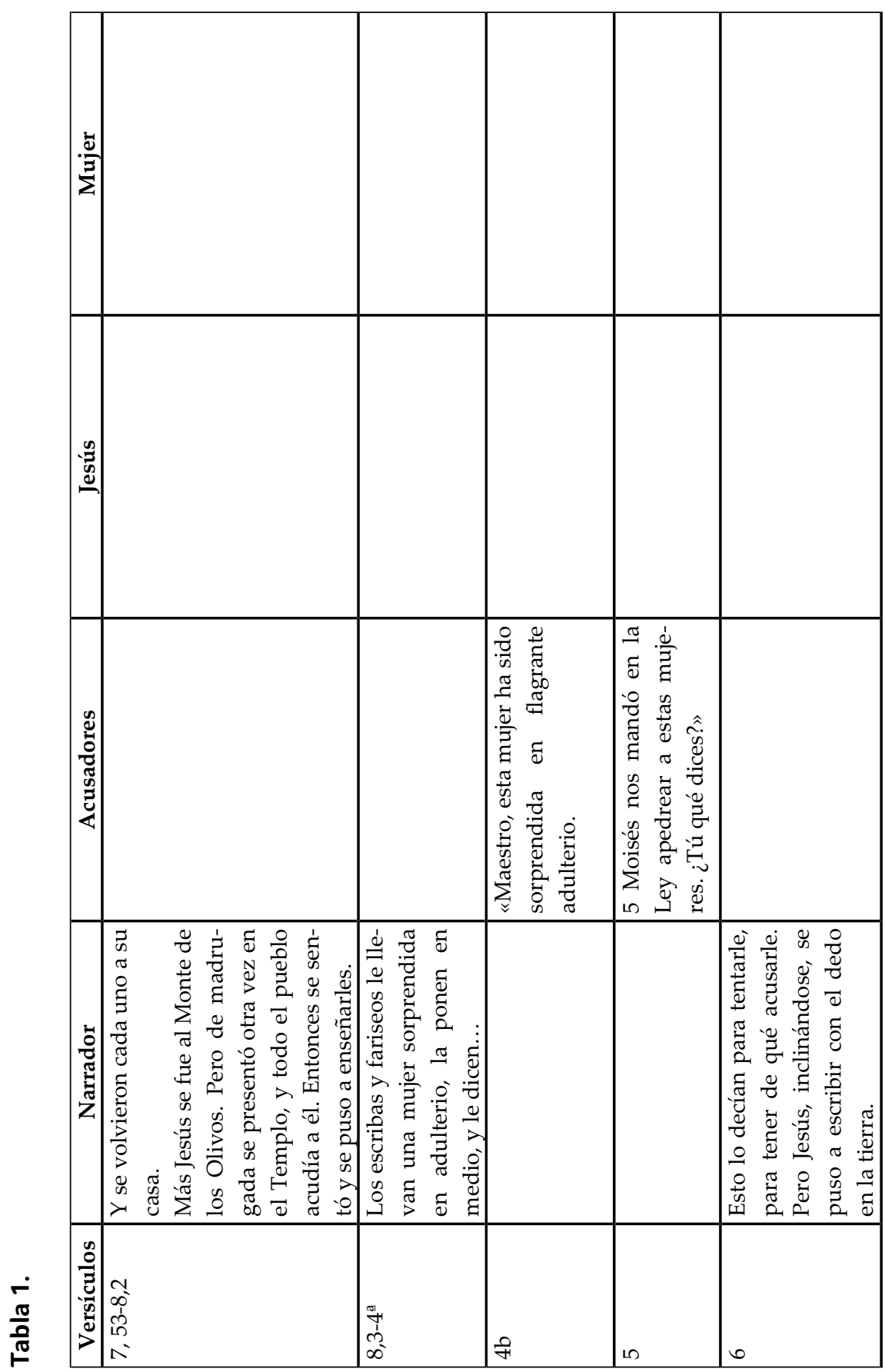




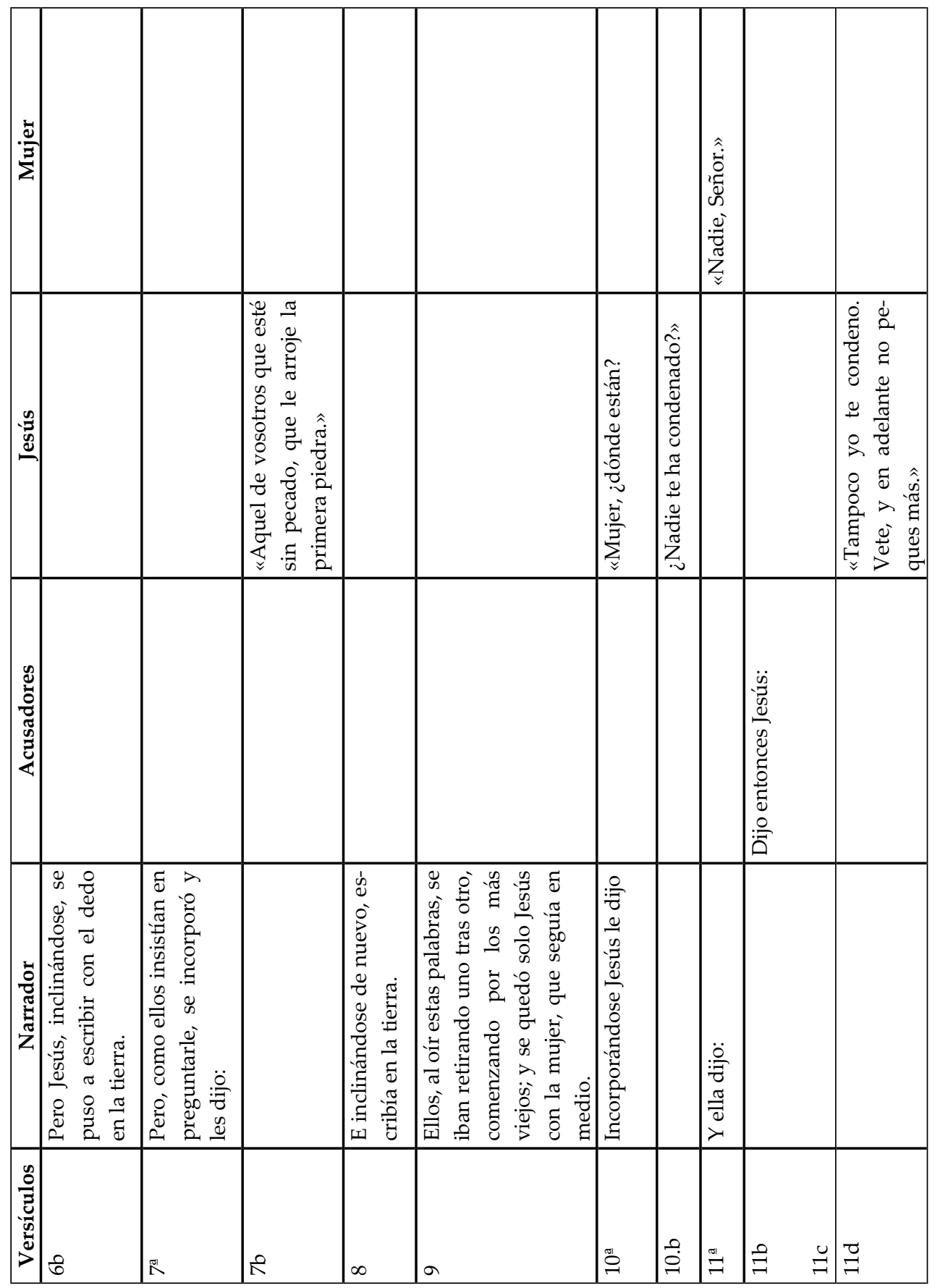




\subsection{Estructura quiásmica del texto:}

I. Introducción $(7,53-8,2)$

II. Trampa a Jesús $\left(8,3-6^{\underline{a}}\right)$
A. Introducción del narrador (8,3-4 $\left.4^{\mathrm{a}}\right)$
B. Los acusadores ------------------- el pecado de la mujer $(8,4 b)$
Presentan el caso --------------------- Moisés y Jesús $(8,5)$
A. Conclusión del narrador, intención de los escribas y fariseos $\left(8,6^{\underline{a}}\right)$

III. Jesús escapa de la trampa $(8,6 b-9)$
A. Introducción del narrador, silencio de Jesús $(8,6 b)$
B. Respuesta de Jesús--------------insistencia de los acusadores $(8,7)$----------- condición para ejecutar la lapidación $(8,7 \mathrm{~b})$
A. Conclusión del narrador El silencio final de Jesús $(8,8)$ -------- Retirada de los acusadores $(8,9)$

IV. Solución del caso por parte de Jesús
A. Pregunta de Jesús $(8,10)$
B. Respuesta de la mujer $(8,11 a-b)$
A. Sentencia final de Jesús (8,11, d-c) (Sánchez, p. 2010, p. 28).

En el sentido quiásmico del relato, se puede hacer un acercamiento de la siguiente manera:

En la primera sentencia, Jesús sale victorioso frente a los acusadores (B) en donde se resalta a renglón seguido la doble acción de Jesús de inclinarse y escribir en la tierra (A y A) (Sánchez, p. 2010, p. 28). El estilo de las sentencias permite reconocer la importancia de la escena, la cual se resuelve de modo imperativo en donde el desenlace es la no condenación y el cambio de paradigma para la acusada que sale exonerada de su culpabilidad, con el compromiso de cambio. 


\subsection{Análisis de términos}

En esta parte de nuestro estudio, nos dedicaremos al estudio de las palabras del texto que nos permitirá conocer el texto en sí mismo y a descubrir la intencionalidad del autor con la escogencia de dichas palabras y no otras.

\subsection{Significado denotativo y connotativo}

En primer lugar, veremos la denotación de las palabras y su conjunto de significados, debido a su riqueza etimológica o por el constante uso.

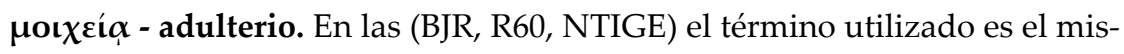

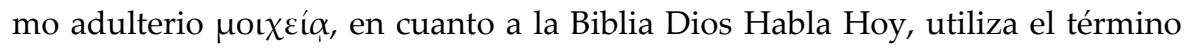
antecedido de la palabra cometiendo, gerundio del verbo cometer que es un verbo transitivo que significa realizar una acción que constituye un error o un delito cometer un atropello. En el testamento interlineal, la palabra en griego es

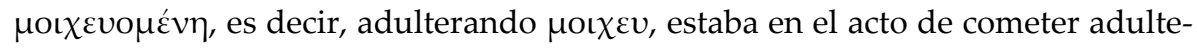
rio lo cual connota una voz activa, o seducir o ser seducido en el caso femenino se aplica cometer adulterio.

En el AT se prohibía la violación por adulterio, se intentaba proteger el matrimonio (Ex 20,14; Dt 5,18). La transgresión es la pena de muerte (Dt 22,22). El marido podía solicitar que fuese juzgada, pero no podía tomar acciones contra ella (Mt 1,19) (Kittel, 2003, p. 529).

$\lambda_{\mathbf{\imath}} \theta \alpha \dot{\zeta} \zeta \mathbf{\imath} \mathbf{v}$ - apedrear. La palabra es el sustantivo del verbo $\lambda \iota \theta o \beta o \lambda \varepsilon ́ \omega$, todas las traducciones, tanto literales como dinámicas utilizan $\lambda \iota \theta \alpha \dot{\alpha} \varepsilon \iota v$, lapidar o apedrear, tirar piedras. Esta acción solo es posible una vez se haya comprobado el delito, lo cual implicaba que hubiese testigos que presenciaran el hecho.

$\pi \varepsilon \iota \Longleftrightarrow \alpha ́ \zeta o v \tau \varepsilon \varsigma$ - tentar. Esta palabra proviene del verbo $\pi \varepsilon \iota \varrho \alpha ́ \zeta \omega$, tentado, tentar, tentándole, para hacer la prueba de, para intentar, prueba, tentar.

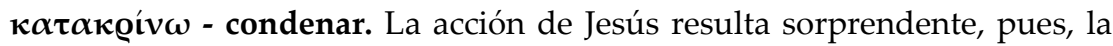
mujer resulta siendo absuelta de su acusación y liberada del castigo de la muerte, que según la ley debía ser juzgada.

Tabla 2.

\begin{tabular}{|c|c|c|c|}
\hline $5 b$ & $\lambda ı \theta \alpha ́ \zeta \varepsilon ı v$ & apedrear & verbo \\
\hline $3 b$ & 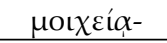 & adulterio & sustantivo, femenino \\
\hline $6 a$. & $\pi \varepsilon \iota \varrho \alpha ́ \omega \omega$ & tentar & verbo \\
\hline $10 \mathrm{~b}$ & 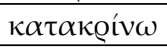 & condenar & verbo \\
\hline
\end{tabular}




\subsection{Organización de las palabras}

Por medio de este cuadro clasificaremos las palabras más comunes dentro de la perícopa, que nos permite comprender el contenido y la intencionalidad.

Tabla 3.

\begin{tabular}{|l|c|c|c|c|c|c|c|c|c|c|c|c|c|}
\hline \multicolumn{1}{|c|}{ Palabras } & $\mathrm{v} .53$ & $\mathrm{v} .1$ & $\mathrm{v} .2$ & $\mathrm{v} .3$ & $\mathrm{v} .4$ & $\mathrm{v} .5$ & $\mathrm{v} .6$ & $\mathrm{v} .7$ & $\mathrm{v} .8$ & $\mathrm{v.9}$ & $\mathrm{v} .10$ & $\mathrm{v} .11$ & Total \\
\hline Monte - Olivos & & $\mathrm{x}$ & & & & & & & & & & & $1 \mathrm{x}$ \\
\hline Mujer & & & & $\mathrm{x}$ & $\mathrm{x}$ & $\mathrm{x}$ & & & & $\mathrm{x}$ & $\mathrm{x}$ & & $5 \mathrm{x}$ \\
\hline Adulterio & & & & $\mathrm{x}$ & $\mathrm{x}$ & & & & & & & & $2 \mathrm{x}$ \\
\hline Piedra & & & & & & $\mathrm{x}$ & & & $\mathrm{x}$ & & & & $2 \mathrm{x}$ \\
\hline Pecado & & & & & & & & $\mathrm{x}$ & & & & $\mathrm{x}$ & $2 \mathrm{x}$ \\
\hline Ley & & & & & & $\mathrm{x}$ & & & & & & & $1 \mathrm{x}$ \\
\hline Tentar & & & & & & & $\mathrm{x}$ & & & & & & $1 \mathrm{x}$ \\
\hline Inclinarse & & & & & & & $\mathrm{x}$ & & $\mathrm{x}$ & & & & $2 \mathrm{x}$ \\
\hline Templo & & $\mathrm{x}$ & & & & & & & & & & & $1 \mathrm{x}$ \\
\hline Sorprendida & & & & $\mathrm{x}$ & $\mathrm{x}$ & & & & & & & & $2 \mathrm{x}$ \\
\hline Incorporarse & & & & & & & & $\mathrm{x}$ & & & $\mathrm{x}$ & & $2 \mathrm{x}$ \\
\hline Escribir & & & & & & & $\mathrm{x}$ & & $\mathrm{x}$ & & & & $2 \mathrm{x}$ \\
\hline Sentarse & & & $\mathrm{x}$ & & & & & & & & & & $1 \mathrm{x}$ \\
\hline Irse & & & & & & & & & & & & $\mathrm{x}$ & $1 \mathrm{x}$ \\
\hline Decir - dicen & & & & & $\mathrm{x}$ & & $\mathrm{x}$ & $\mathrm{x}$ & & & $\mathrm{x}$ & $\mathrm{x}$ & $5 \mathrm{x}$ \\
\hline
\end{tabular}

La estadística de la Tabla 3, nos permite ver claramente que las palabras y los verbos más frecuentes en repetirse están relacionados con la mujer, luego las acciones de Jesús frente a los fariseos y escribas y a la mujer utilizando el verbo decir, referido a ella y a ellos. Después en un orden menor: adulterio, pecado etc.

\subsection{Palabras independientes y dependientes}

Dentro de la palabras independientes, se pueden percibir algunas con sentido propio, las cuales van ligadas a la acción principal del relato. 
Ejemplo:

Tabla 4.

\begin{tabular}{|c|c|c|c|}
\hline $\begin{array}{l}\text { Greek New } \\
\text { Testament }\end{array}$ & Reina Valera 1960 & Dios Habla Hoy & $\begin{array}{c}\text { Biblia de Jerusalén } \\
1975\end{array}$ \\
\hline \multirow{2}{*}{ 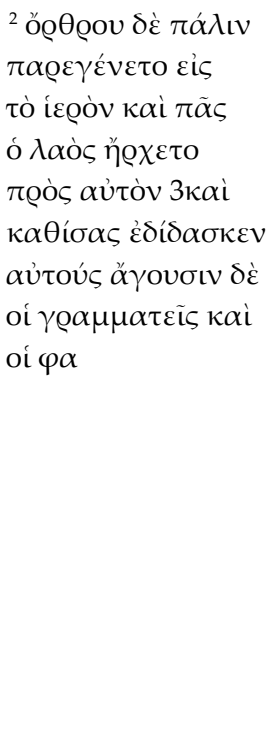 } & $\begin{array}{l}{ }^{2} \text { Y por la mañana } \\
\text { volvió al templo, y } \\
\text { todo el pueblo vino } \\
\text { a él; y sentado él, } \\
\text { les enseñaba. }\end{array}$ & $\begin{array}{l}{ }^{2} \text { y al día siguiente, } \\
\text { al amanecer, volvió } \\
\text { al templo. La gente } \\
\text { se le acercó, y él se } \\
\text { sentó y comenzó a } \\
\text { enseñarles. }\end{array}$ & $\begin{array}{l}{ }^{2} \text { Pero de madruga- } \\
\text { da se presentó otra } \\
\text { vez en el Templo, y } \\
\text { todo el pueblo acu- } \\
\text { día a él. Entonces } \\
\text { se sentó y se puso a } \\
\text { enseñarles. }\end{array}$ \\
\hline & $\begin{array}{l}{ }^{3} \text { Entonces los escri- } \\
\text { bas y los fariseos le } \\
\text { trajeron una mujer } \\
\text { sorprendida en } \\
\text { adulterio; y ponién- } \\
\text { dola en medio, }\end{array}$ & $\begin{array}{l}{ }^{3} \text { Los maestros de } \\
\text { la ley y los fariseos } \\
\text { llevaron entonces a } \\
\text { una mujer, a la que } \\
\text { habían sorprendido } \\
\text { cometiendo adulte- } \\
\text { rio. La pusieron en } \\
\text { medio de todos los } \\
\text { presentes, }\end{array}$ & $\begin{array}{l}{ }^{3} \text { Los escribas y } \\
\text { fariseos le llevan } \\
\text { una mujer sorpren- } \\
\text { dida en adulterio, la } \\
\text { ponen en medio }\end{array}$ \\
\hline
\end{tabular}

\subsection{Palabras independientes}

Tabla 5.

\begin{tabular}{|c|c|c|c|c|c|}
\hline \multicolumn{2}{|c|}{ Sustantivos } & \multicolumn{2}{|c|}{ Verbos } & \multicolumn{2}{|r|}{ Adjetivos } \\
\hline Pueblo & 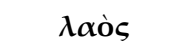 & volver & 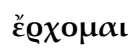 & Todos & $\pi \tilde{\alpha} \varsigma, \pi \tilde{\alpha} \sigma \alpha, \pi \tilde{\alpha} v$ \\
\hline $\begin{array}{c}\text { Escribas } \\
\text { Fariseos } \\
\text { Mujer }\end{array}$ & 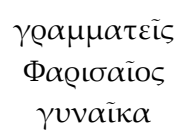 & $\begin{array}{l}\text { Enseñar } \\
\text { Sentarse }\end{array}$ & $\begin{array}{c}\delta \mathrm{\iota} \delta \alpha ́ \alpha \kappa \omega \\
\kappa \alpha \theta i \zeta \omega\end{array}$ & & \\
\hline
\end{tabular}




\subsection{Palabras dependientes}

Tabla 6.

\begin{tabular}{|c|c|c|c|c|c|c|c|}
\hline \multicolumn{2}{|c|}{ Pronombres } & \multicolumn{2}{|c|}{ Preposiciones } & \multicolumn{2}{|c|}{ Conjunciones } & \multicolumn{2}{|c|}{ Artículos } \\
\hline le & $\alpha u ̛$ tòv & a & тஹò & $\mathrm{y}$ & $\kappa \alpha \grave{\mathrm{i}}$ & los & oí \\
\hline
\end{tabular}

Prestamos atención a la palabra mujer ( $\gamma v v \alpha \tilde{i} \kappa \alpha)$ sustantivo femenino precedida del verbo y el pronombre personal le, ( $\alpha \dot{u} \tau o ̀ v)$. Se evidencia claramente que se suprime escribas y fariseos remplazado por (le), donde la presentación hacia la mujer no es voluntaria sino obligada y los responsables directos de la presentación son los fariseos y escribas, el papel del pueblo es el de espectador.

\subsection{Delimitación de las oraciones}

En este apartado queremos hacer un análisis de las oraciones principales que la perícopa nos plantea al inicio del relato. Ejemplo:

Los escribas y fariseos le llevan una mujer sorprendida en adulterio, la ponen en medio

Sujeto predicado complemento

y le dicen: Maestro, esta mujer ha sido sorprendida en flagrante adulterio.

Sujeto predicado

En el ejemplo anterior sobre oraciones principales, notamos que las dos oraciones están unidas por una conjunción y enseguida del verbo, cuya acción es informativa, puesto que no están dando una sentencia. "Recordemos que el marido podía solicitar que se le juzgue, pero no estaba obligado a tomar acciones contra ella" (Kittel, 2003, p. 529).

El verbo $\kappa \alpha \tau \alpha \lambda \alpha \mu \beta \alpha ́ v \omega$, en griego alcanzo, tomar posesión de, aprovechar. Descubrimos por tanto, que según la acusación, la mujer estuvo en posesión del 
acto. La presencia de Jesús, como $\delta \iota \alpha ́ \sigma \kappa \alpha \lambda$ o y reconocido así por sus adversarios, confirma la incapacidad de tomar acciones por su cuenta $(\mathrm{Nm} 5,16)$.

\subsection{Comparación de traducciones}

Tabla 7.

\begin{tabular}{|c|c|c|}
\hline $\begin{array}{c}\text { Biblia de Jerusalén } \\
\text { BDJ }\end{array}$ & $\begin{array}{c}\text { Reina Valera } 60 \\
\text { R60 }\end{array}$ & $\begin{array}{c}\text { Dios Habla Hoy } \\
\text { DHH }\end{array}$ \\
\hline $\begin{array}{l}\text { 7,53. Y se volvieron cada } \\
\text { uno a su casa. }\end{array}$ & 53 Cada uno se fue a su casa; & 53 Cada uno se fue a su casa. \\
\hline $\begin{array}{l}\text { 8,1 Más Jesús se fue al Monte } \\
\text { de los Olivos. }\end{array}$ & $\begin{array}{l}\text { 8. y Jesús se fue al Monte de } \\
\text { los Olivos. }\end{array}$ & $\begin{array}{l}\text { 8, } 1 \text { Pero Jesús se dirigió al } \\
\text { Monte de los Olivos. }\end{array}$ \\
\hline $\begin{array}{l}\text { 2. Pero de madrugada se pre- } \\
\text { sentó otra vez en el Templo, } \\
\text { y todo el pueblo acudía a él. } \\
\text { Entonces se sentó y se puso a } \\
\text { enseñarles. }\end{array}$ & $\begin{array}{l}\text { 1, Y por la mañana volvió } \\
\text { al templo, y todo el pueblo } \\
\text { vino a él; y sentado él, les } \\
\text { enseñaba. }\end{array}$ & $\begin{array}{l}{ }^{2} \text { y al día siguiente, al amane- } \\
\text { cer, volvió al templo. La gen- } \\
\text { te se le acercó, y él se sentó y } \\
\text { comenzó a enseñarles. }\end{array}$ \\
\hline $\begin{array}{l}3 \text { Los escribas y fariseos le } \\
\text { llevan una mujer sorprendi- } \\
\text { da en adulterio, la ponen en } \\
\text { medio, }\end{array}$ & $\begin{array}{l}{ }^{3} \text { Entonces los escribas y los } \\
\text { fariseos le trajeron una mu- } \\
\text { jer sorprendida en adulterio; } \\
\text { y poniéndola en medio, }\end{array}$ & $\begin{array}{l}3 \text { Los maestros de la ley y los } \\
\text { fariseos llevaron entonces a } \\
\text { una mujer, a la que habían } \\
\text { sorprendido cometiendo } \\
\text { adulterio. La pusieron en } \\
\text { medio de todos los presentes, }\end{array}$ \\
\hline $\begin{array}{l}4 \text { y le dicen: «Maestro, esta } \\
\text { mujer ha sido sorprendida } \\
\text { en flagrante adulterio. }\end{array}$ & $\begin{array}{l}{ }^{4} \text { le dijeron: Maestro, esta } \\
\text { mujer ha sido sorprendi- } \\
\text { da en el acto mismo de } \\
\text { adulterio. }\end{array}$ & $\begin{array}{l}4 \text { y dijeron a Jesús: --Maestro, } \\
\text { esta mujer ha sido sorpren- } \\
\text { dida en el acto mismo de co- } \\
\text { meter adulterio. }\end{array}$ \\
\hline $\begin{array}{l}5 \text { Moisés nos mandó en la } \\
\text { Ley apedrear a estas mujeres. } \\
\text { ¿Tú qué dices?» }\end{array}$ & $\begin{array}{l}{ }^{5} \text { Y en la ley nos mandó Moi- } \\
\text { sés apedrear a tales muje- } \\
\text { res. Tú, pues, ¿qué dices? }\end{array}$ & $\begin{array}{l}5 \text { En la ley, Moisés nos orde- } \\
\text { nó que se matara a pedradas } \\
\text { a esta clase de mujeres. ¿Tú } \\
\text { qué dices? } \\
\end{array}$ \\
\hline $\begin{array}{l}6 \text { Esto lo decían para tentarle, } \\
\text { para tener de qué acusarle. } \\
\text { Pero Jesús, } \\
\text { inclinándose, se puso a es- } \\
\text { cribir con el dedo en la tierra. }\end{array}$ & $\begin{array}{l}{ }^{6} \text { Más esto decían tentándole, } \\
\text { para poder acusarle. Pero Je- } \\
\text { sús, inclinado hacia el suelo, } \\
\text { escribía en tierra con el dedo. }\end{array}$ & $\begin{array}{l}6 \text { Ellos preguntaron esto para } \\
\text { ponerlo a prueba, y tener así } \\
\text { de qué acusarlo. Pero Jesús se } \\
\text { inclinó y comenzó a escribir } \\
\text { en la tierra con el dedo. }\end{array}$ \\
\hline
\end{tabular}




\begin{tabular}{|c|c|c|}
\hline $\begin{array}{c}\text { Biblia de Jerusalén } \\
\text { BDJ }\end{array}$ & $\begin{array}{c}\text { Reina Valera } 60 \\
\text { R60 } \\
\end{array}$ & $\begin{array}{c}\text { Dios Habla Hoy } \\
\text { DHH } \\
\end{array}$ \\
\hline $\begin{array}{l}7 \text { Pero, como ellos insistían } \\
\text { en preguntarle, se incorporó } \\
\text { y les dijo: «Aquel de voso- } \\
\text { tros que esté sin pecado, que } \\
\text { le arroje la primera piedra.» }\end{array}$ & $\begin{array}{l}{ }^{7} \text { Y como insistieran en pre- } \\
\text { guntarle, se enderezó y les } \\
\text { dijo: El que de vosotros esté } \\
\text { sin pecado sea el primero en } \\
\text { arrojar la piedra contra ella. }\end{array}$ & $\begin{array}{l}7 \text { Luego, como seguían pre- } \\
\text { guntándole, se enderezó y } \\
\text { les dijo: - Aquel de ustedes } \\
\text { que no tenga pecado, que le } \\
\text { tire la primera piedra. }\end{array}$ \\
\hline $\begin{array}{l}8 \text { E inclinándose de nuevo, } \\
\text { escribía en la tierra. }\end{array}$ & $\begin{array}{l}{ }^{8} \mathrm{E} \text { inclinándose de nuevo } \\
\text { hacia el suelo, siguió escri- } \\
\text { biendo en tierra. }\end{array}$ & $\begin{array}{l}8 \mathrm{Y} \text { volvió a inclinarse y si- } \\
\text { guió escribiendo en la tierra. }\end{array}$ \\
\hline $\begin{array}{l}9 \text { Ellos, al oír estas palabras, } \\
\text { se iban retirando uno tras } \\
\text { otro, comenzando por los } \\
\text { más viejos; y se quedó solo } \\
\text { Jesús con la mujer, que se- } \\
\text { guía en medio. }\end{array}$ & $\begin{array}{l}{ }^{9} \text { Pero ellos, al oír esto, acu- } \\
\text { sados por su consciencia, sa- } \\
\text { lían uno a uno, comenzando } \\
\text { desde los más viejos hasta } \\
\text { los postreros; y quedó solo } \\
\text { Jesús, y la mujer que estaba } \\
\text { en medio. }\end{array}$ & $\begin{array}{l}9 \text { Al oír esto, uno tras otro } \\
\text { comenzaron a irse, y los pri- } \\
\text { meros en hacerlo fueron los } \\
\text { más viejos. Cuando Jesús se } \\
\text { encontró solo con la mujer, } \\
\text { que se había quedado allí, }\end{array}$ \\
\hline $\begin{array}{l}10 \text { Incorporándose Jesús le } \\
\text { dijo: «Mujer, ¿dónde están? } \\
\text { ¿Nadie te ha condenado?» }\end{array}$ & $\begin{array}{l}{ }^{10} \text { Enderezándose Jesús, y } \\
\text { no viendo a nadie sino a la } \\
\text { mujer, le dijo: Mujer, ¿dónde } \\
\text { están los que te acusaban? } \\
\text { ¿Ninguno te condenó? }\end{array}$ & $\begin{array}{l}10 \text { se enderezó y le preguntó: } \\
\text {--Mujer, ¿dónde están? ¿Nin- } \\
\text { guno te ha condenado? }\end{array}$ \\
\hline $\begin{array}{l}11 \text { Ella respondió: «Nadie, } \\
\text { Señor.» Jesús le dijo: «Tam- } \\
\text { poco yo te condeno. Vete, y } \\
\text { en adelante no peques más.» }\end{array}$ & $\begin{array}{l}11 \text { Ella dijo: Ninguno, Señor. } \\
\text { Entonces Jesús le dijo: Ni yo } \\
\text { te condeno; vete, y no pe-- } \\
\text { ques más. }\end{array}$ & $\begin{array}{l}11 \text { Ella le contestó: -Nin- } \\
\text { guno, Señor. Jesús le dijo: } \\
\text {-Tampoco yo te condeno; } \\
\text { ahora, vete y no vuelvas a } \\
\text { pecar. }\end{array}$ \\
\hline
\end{tabular}

\subsubsection{Observaciones}

La primera comparación nos arroja los siguientes resultados:

\section{v. 53.}

- La BDJ, utiliza la conjunción " $y$ ", mientras las otras la omiten. De igual manera, utiliza un verbo en pretérito indefinido como acción principal. R60 y DHH, también lo utilizan como pretérito, pero el verbo ir ("fue").

v. 8.1.

- Las tres versiones utilizan conjunción. BDJ, utiliza la conjunción "más", R60, utiliza la " $y$ "; DHH, utiliza una conjunción adversativa ("pero"), que se contrapone al inmediato anterior. 
v. 2.

- La BDJ, traduce "al amanecer", R60, utiliza la palabra "por la mañana", mientras que $\mathrm{DHH}$, une las dos palabras con una conjunción, “al día siguiente, al amanecer".

v. 3 .

- Solo BDJ, utiliza "ponen". La R60, utiliza el gerundio "poniéndola". Solo DHH, pone el pretérito indefinido "pusieron" como complemento en medio de todos los presentes.

v. 4 .

- $\quad$ BJR, utiliza la palabra "flagrante", mientras que R60 y DHH, traducen el acto mismo, con el gerundio "cometiendo".

v. 5 .

- $\quad$ BJR. La palabra que utilizan para referirse a Moisés sobre la ley es: "nos mandó". No utiliza conjunciones a diferencia de las otras traducciones.

- R60 utiliza, "nos mandó", mientras que DHH, dice "ordenó".

- La tres utilizan “¿tú que dices?”.

v. 6 .

- $\quad$ BJR, dice "tentarle", R60, “tentándolo", DHH, "acusarlo".

v. 7 .

- DHH, utiliza el "ustedes", R60 y BJR, "vosotros", sin embargo hay una diferencia en la R60, que aumenta una palabra, "ella" que no está en las otra traducciones.

v. 8 .

- Entre las tres versiones hay una variación en el artículo, BJR, "en la", R60, “en”, y DHH, “en la”.

v. 9.

- "Salían" BJR, "retirarse" R60, "irse" DHH, son los verbos principales, que corresponden a cada una de las traducciones. La palabra consciencia solo aparece en la Reina Valera. 
v. 10.

- R60, es la traducción que más cambia, "y no viendo a nadie", expresión única dentro de las comparaciones. La expresión "los que", se utiliza para entender el diálogo de Jesús con la mujer.

- BJR, utiliza la palabra "incorporase", mientras que R60 y DHH, utilizan la palabra "enderezarse".

v. 11.

- BJR, utiliza la frase "en adelante", R60, la conjunción " $y^{\prime}$, y DHH, agrega dos palabras, "ahora" y "no vuelvas".

\section{Análisis exegético}

Dentro del análisis exegético que hacemos a la perícopa de la mujer adúltera comenzaremos preguntándonos: ¿Por qué esta perícopa está en el Evangelio de Juan? ¿Cuál fue su sentido teológico para ubicarla en este sitio?

Secundino Castro afirma que el texto joánico, viene presentando la figura de Jesús superior a la de Moisés desde el capítulo 6. Si lo vemos desde el capítulo 7, Jesús presenta una nueva agua, en el capítulo 8. Jesús es anterior a Abraham quien es la columna del pueblo hebreo, de ahí que la intencionalidad sea resaltar la divinidad de Jesús. En el culmen del relato se da la revelación pública de la divinidad de Jesús (Castro, 2001, p. 189).

La ubicación de la perícopa en este espacio nos presenta a un Jesús superior a las figuras del AT. La actitud de Jesús postrado ante la mujer, lo muestra compasivo y humano. De modo que, el autor encargado de empotrar la perícopa en este espacio no lo hizo sin causa de conocimiento. "La perícopa tiene su lógica, pues Jesús en los pasaje anteriores viene advirtiendo sobre los juicios externos, $(7,20)$. El no señalamiento de Jesús $(8,11)$ que no lanza ningún juicio contra la mu-

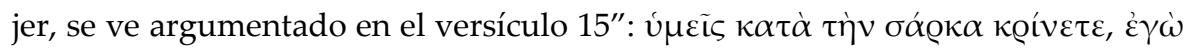

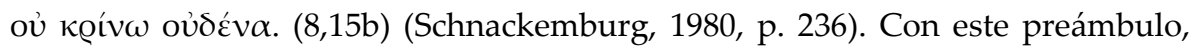
damos inicio a una reflexión exegética sobre el texto.

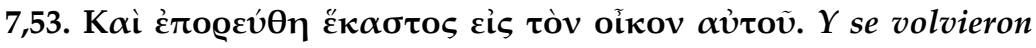
cada uno a su casa.

Recordemos que en los pasajes anteriores se plantea la disputa de los fariseos, Jesús y Nicodemo. El versículo es un modo de terminar la disputa. Volverse 
a casa dentro del Evangelio de Juan solo aparece en este pasaje. Volver a casa es una acción dinámica que denota movimiento, el verbo que le acompaña es

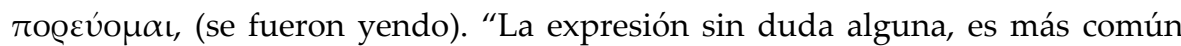
en los sinópticos (Mt, 9,6; Mc 2,11; Lc 5,24). Por su parte, Juan utiliza el verbo

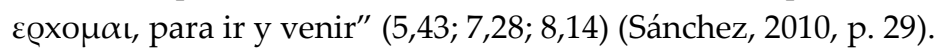

Por su parte, la expresión "hacia la casa", está acompañada por un verbo de movimiento compuesto por (Mt 9,6; Mc 2,11; Lc 5,24), . (Mt 9,7; Mc 2,26; Lc 5,25). “Al respecto, es el verbo que Juan utiliza frecuentemente para designar no solamente el ir y venir, sino la venida de Cristo $(5,43 ; 7,28 ; 8,14.42 ; 9,39 ; 10,10 ; 12,47$; 13,3; 16,28; 18,37)" (Sánchez, 2010, p. 29).

Es claro que el versículo termina la acción y da pie a una nueva perícopa, sin embargo en la manera de cerrarlo deja a la expectativa al lector sobre lo que puede sobrevenir; así podemos afirmar que el versículo tiene un tinte introductorio, después de haber despedido a los contrincantes (guardias, los fariseos, Nicodemo). Por otro lado, vemos que el contexto original es desconocido, pero parece presuponer el relato sinóptico de la pasión, donde Jesús pasó los días en Jerusalén enseñando (Mc 11,11).

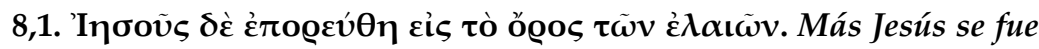 al Monte de los Olivos.}

La acción presentada por Jesús de ir al monte, guarda cierto paralelo con Lc 21, 37, que nos presenta a un Jesús enseñando en el templo y luego se retira al monte a orar. La tradición sinóptica enfatiza sobre la constante presencia de Jesús en el monte (Mt 26, 30; 21,1; Lc 19,29; Mc 11,1, 13,3).

Por otro lado, la presencia de Jesús en el templo no es orante, es de maestro, enseña; por ello la característica de estar sentado $(8,2)$. Esta acción permite afirmar la cualidad real, jurídica y sacerdotal de la enseñanza de Jesús, de modo que, la presencia del pueblo acudiendo a su enseñanza es un solemne acto de reconocimiento de su autoridad.

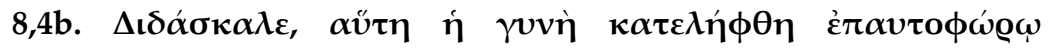

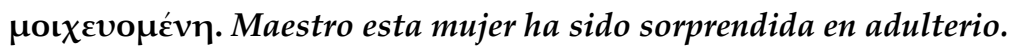

La presencia de los escribas y fariseos que presentan a la mujer, piden la opinión de Jesús, mientras le recuerdan el castigo según la ley mosaica. No hay una claridad sobre lo que se le pide a Jesús. “Dt 22,23, pedía que una mujer desposada que cometiera adulterio fuera lapidada, a diferencia del Lv 20,10 y Dt 22,22, que prescribían la muerte sin especificar la forma de ejecución" (Brown, 2010, p. 446). 
Es posible que la petición hacia Jesús estaba orientada a que legitimara tal sentencia. Llama la atención que los fariseos y escribas pongan a Jesús al nivel

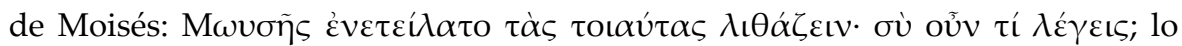
cual supone que Jesús no es solo un maestro que interpreta, sino que tiene capacidad de legislar $(8,7$.$) , aun reconociendo la intencionalidad de ponerle trampa,$ situación que se puede comparar con los sinópticos que buscaban pruebas para acusarlo (Lc 6,7; Mc 3,2).

La excusa perfecta, es presentarle a la mujer para así acusarlo de transgresor de la ley. Recordemos que Jesús ya viene en conflicto con el pasaje anterior por no respetar el sábado (5,1-47). Los escribas y los fariseos contraponen la autoridad de la ley a la de Jesús. Posiblemente Jesús iba a ser acusado de transgresor de la ley de Moisés, cuya autoridad legislativa en la tradición de Israel está fuera de discusión; por lo tanto, la intención de los escribas y fariseos no es conocer la interpretación que Jesús hace de la ley, sino "tenderle una trampa" (Sánchez, 2010, p. 31). Sin embargo, el hecho de llevar la mujer ante Jesús supone una intencionalidad de nombrarlo juez, cuyo propósito es dar un veredicto. De esta forma, Jesús es comparado con los jueces señalados en el Deuteronomio, quienes tenían la potestad de dirimir un Pleito de sangre:

Si tienes que juzgar un caso demasiado difícil para ti, una causa de sangre, de colisión de derechos, o de lesiones, un litigio cualquiera en tus ciudades, te levantarás, subirás al lugar elegido por Yahveh tu Dios, y acudirás a los sacerdotes levitas y al juez que entonces esté en funciones. Ellos harán una investigación y te indicarán el fallo de la causa. Te ajustarás al fallo que te hayan indicado en este lugar elegido por Yahveh, y cuidarás de actuar conforme a cuanto te hayan enseñado (Dt 17,8-10).

El texto del Deuteronomio supone tres acciones. 1. Quienes acuden a llevar el caso, no tienen autoridad para juzgar, solo lo hace el juez en el lugar indicado. 2. Solo el juez dará la sentencia pertinente. 3 . Han de acoger la sentencia emitida por el juez.

En el caso de la mujer adúltera, podemos ver las tres realidades. 1. El pueblo y los ancianos acuden a Jesús, cuyo lugar de juicio es el templo para indicar que Dios está presente y darle peso y credibilidad a la sentencia. 2. Jesús emite la sentencia en dos partes, a) contra los acusadores, b) a favor de la mujer, lo cual desarrollaremos más adelante. 3. La acción de la sentencia es inmediata, pues sueltan las piedras como signo de acogida de la sentencia. 
Por otro lado, el silencio de Jesús, frente al hecho ha sido interpretado de múltiples formas, para algunos es la manera de obviar la respuesta, para otros es la invitación a meditar tal sentencia, sin embargo, el contexto parece suponer que, la ley dada por Moisés escrita en la piedra por el dedo de Dios, ahora Jesús escribe una nueva ley que cuenta con la debilidad humana, que le da la posibilidad de borrar el pasado; es una ley para el hombre que es terreno frágil. Jesús agachado ante la mujer, signo de no juzgar $(8,15)$, en sintonía con el lavatorio de los pies, muestra al maestro purificando al hombre de su suciedad y mostrándole el mandamiento del amor $(13,1, \mathrm{ss})$.

De igual manera, la advertencia implícita en las palabras de Jesús debe interpretarse como una referencia a la ley. “Dt 17,7, especifica que los que actúan como testigos contra un acusado, son responsables de su muerte en caso de que se le condene a morir" (Brown, 2010, p. 446).

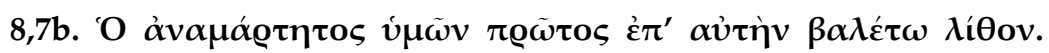
Aquel de vosotros que esté sin pecado, que le arroje la primera piedra.

Ante la insistencia, de los acusadores, la escena que es un apotegma biográfico en donde se tiende una trampa, la cual exige una sentencia que demuestre sabiduría: "por ejemplo, (Mc 12,13-17) sobre el tributo ofrecido al César" (Brown, 2010, p. 446).

La proclama de tirar la piedra, es una referencia como ya se ha hecho mención, al levantamiento de mano sobre el reo de muerte, lo cual lo convierte en testigo responsable de la condena de muerte (Dt 17,7). El testigo que alza la mano

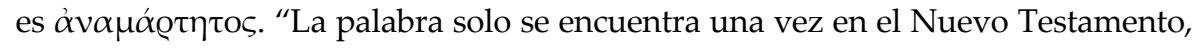
pero se encuentra en los LXX para indicar al inocente en contraposición al pecador

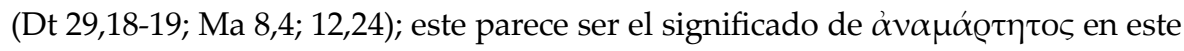
contexto: el inocente en sentido general, y no solo adulterio"' (Sánchez, 2010, p. 38).

Por lo anterior, se puede inferir, que la afirmación de Jesús no es solo una palabra en un juicio, es un mandamiento que implícitamente pide juzgarse personalmente antes de juzgar al otro. La sentencia de Jesús interpela a los acusadores implícitamente para que se haga presente también el hombre adúltero que hasta el momento sigue en el anonimato.

El silencio de Jesús, después de su parecer, obliga a los otros a dar su parecer, y tomar una opción. De ahí que, la retirada empezando por los ancianos, lo que simboliza la presencia de los dirigentes del pueblo, la tradición y autoridad, ante Jesús, carece de sentido. "La suya era una ley de piedra; la de Jesús es una ley en tierra; su aplicación no es fija, se adapta a cada caso, a cada hombre" (Castro, 2001, p. 189). 


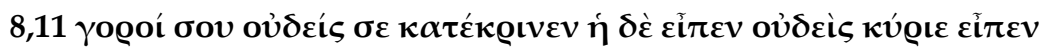

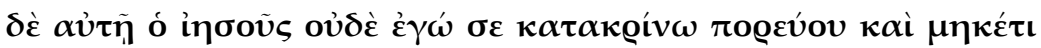

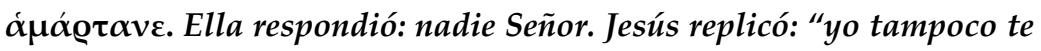
condeno. Vete y no vuelvas a pecar".

La lección final del relato no es que el pecado carezca de importancia o que Dios no esté dispuesto a castigarlo, sino que Dios extiende su misericordia al pecador, para que este se aparte de su pecado (Brown, 2010, p. 467). Jesús demuestra con esta acción de absolución que no es uno de ellos; "la mujer libre puede marcharse" (Brown et al., 1972, p. 558). Ante Nicodemo ya había manifestado que no vino al mundo para condenar $(3,17)$.

La absolución de Jesús termina con un doble mandato para la mujer, vete y no peques más. "La expresión aparece 8 veces en el Nuevo Testamento, y su significado es escatológico; lleva una connotación salvífica que en el caso de la mujer se convierte en un llamado a la conversión" (Sánchez, 2010, p. 43). De igual manera, el "vete y desde ahora no peques más", puede identificarse con Jeremías (31,31-33) y (Ez 36,25-27), donde la nueva ley está inscrita en el corazón humano.

\section{Elementos teológicos del texto}

"Yo tampoco te condeno". Esta expresión de Jesús dirigida a la mujer, sintetiza su mensaje fundamental. El Hijo del Hombre como nos los describe el evangelista Juan, no vino a juzgar (Jn 7,19-24. 51; 8,15). Sin embargo, aquel que teniendo la autoridad para juzgar, Jesús, y que también tiene la autoridad formal y moral para condenar, no lo hace, Él terminará juzgado y con intención de ser lapidado (Jn 8,59).

Bien se puede decir que con esta manera de proceder de Jesús, Él hace nuevas todas las cosas (Ap 21,5). Jesús inaugura un nuevo estilo de relación con los menos favorecidos. La misericordia de Dios es el centro de toda su predicación (Splanchnizomai). De ahí que, podamos ver en los Evangelios la actitud de Jesús hacia los pecadores: ejemplo, es amigo de pecadores y publicanos (Lc 7,34). Es acusado de blasfemia por perdonar pecados (Lc 5,21). Acoge a la pecadora en casa de Simón, enseñando el mandamiento fundamental: amar, no solo es amar, sino amar más (Lc 7,47).

Ahora bien, el perdón, visto desde los hombres, aparece casi imposible, el hombre es un deudor, insolvente, (Mt 18,23-35). El pecador es incapaz de 
rehabilitarse ante Dios y cumplir su ley. Sin embargo, desde otra óptica, el perdón es buena noticia (Mc 2,5). La buena noticia es la libre donación que Dios concede al pecador y dicha noticia y perdón están ligadas a la persona de Jesús. Jesús confiere el perdón y aparece como quien tiene autoridad para perdonarlos. Por medio de Jesús, el perdón se vuelve en un acto vivo. Jesucristo perdona al pecador; por ello resulta condenado por quien se apega a la ley. "El perdón, no es un simple acto jurídico sino vital" (Cardona, 2016, p. 24).

La actitud de Jesús ante la mujer, nos pone en el contexto de un Dios que ama al mundo hasta el punto de entregar su hijo (Jn 3,16), para que todos tengamos vida en Él y por Él obtenga el agua viva (Jn 7,37; 4,13s). Por ello, “perdonar es sanar las heridas, resanar la vida" (Cardona, 2016, p. 24).

Ante la respuesta de la mujer: "Ninguno Señor", la respuesta de Jesús, es de no condenación. "Yo tampoco te condeno". Como hemos afirmado, el Hijo del hombre no ha venido a juzgar, puesto que el juicio de Dios nunca ha de ser de condenación del pecador, como nos lo expresa el libro de Miqueas: “¿Qué Dios es como tú, que perdonas la falta y pasas por alto la rebeldía del resto de tu herencia? Él no mantiene su ira para siempre, porque ama la fidelidad. El volverá a compadecerse de nosotros y pisoteará nuestras faltas. Tú arrojarás en lo más profundo del mar todos nuestros pecados" (Mi 7,18).

Ciertamente es Dios el que perdona: "Yo, yo soy el que borró tus transgresiones por amor a mí mismo, y no recordaré tus pecados" (Is 43,25). No se trata de que el pecado carezca de importancia ante los ojos de Dios, sino que se extiende su misericordia al pecador para apartarlo de este estado. Dirá santa Teresa: Con amor castigabas mis delitos... y primero me cansé yo de ofenderte que tú de perdonarme...". Así sucede en este relato de la mujer adúltera; primero recibe la noticia de su no condena y después es llamada a la conversión, en efecto, no es el miedo al castigo, sino la experiencia del amor, la verdadera llamada al arrepentimiento y aún más: a la fe. Como diría el profeta asumiendo la intención de Dios: "Yo no quiero que el malvado muera sino que cambie de conducta y viva" (Ez 18,23).

Por consiguiente, la salvación que Jesús, el enviado del Padre ofrece a quienes creen en Él, no viene del rigorismo ciego de promulgar la ley; no viene de la ley escrita en piedra, sino en el suelo que simboliza el encuentro con la misericordia divina; es la ley que se ponen al servicio del hombre y se aplica según cada caso, respetando la libertad y la dignidad de la persona que la hace capaz de levantarse del pecado y, movida por el perdón compasivo de Dios, poner en práctica el verdadero amor que nace de un corazón reconciliado. 
Jesús intenta en este caso, superar cualquier obstáculo o ideología reduccionista, revestida de falsa misericordia. El espíritu de Jesús reflejado en la perícopa de la mujer adúltera nos muestra que es posible acoger al pecador sin necesidad de ser su cómplice. Jesús no pasa por alto el pecado, no aprueba su conducta, él sabe que el pecado expone a la muerte, pero invita a la mujer a una toma de consciencia: "no peques más". Solo la toma de consciencia de los propios pecados permite colocar al hombre en la situación de no juzgar al pecador, no compartir su pecado, pero sí acogerlo y amarlo a la manera de Cristo.

\section{Un juicio justo: el rescate de la dignidad de la mujer}

Jesús es reconocido como maestro y debe dar una sentencia ante la acusación que hacen de la mujer. Están los argumentos y la forma de proceder según la ley. Jesús en su praxis, exhorta al cumplimento de la ley, examinando la propia vida. De esta manera sale en rescate de la dignidad de la mujer. Jesús es colocado entre la espada y la pared, en principio no le queda más alternativa que asociarse a la praxis de sus adversarios y responder pidiendo la pena de muerte de la mujer. De no hacerlo daría suficientes motivos para ser señalado de actuar contra la Ley de Dios.

\subsection{La mujer ante la ley}

El adulterio en la época de Jesús tanto en Roma como en Israel tenía un control jurídico. Por ejemplo, el emperador Augusto, promulgó la ley Iulia de Coercendis Adulteriis. Según esta ley, el marido tenía derecho a matar al amante de su esposa y aún a la esposa si los sorprendía in fraganti en la propia casa (Dt 22, 22-24). "Si el esposo o el padre renunciaban a este derecho, al cabo de sesenta días cualquier ciudadano romano extraño a la familia podía acusar a los adúlteros y las penas impuestas por la ley eran destierro, confiscación de bienes e imposibilidad de contraer nuevo matrimonio" (Andujar, 2010, p. 43).

Por otro lado, la ley mosaica castiga con la muerte por apedreamiento a las puertas de la ciudad a la mujer adúltera, por ello presentan ante el maestro de Galilea una mujer "que ha sido sorprendida en el acto mismo del adulterio" (Jn 8,4). Cuya argumentación es que aplique o consienta la ley, la pena de muerte. Si Jesús fuese un legalista extremo debería haberla aprobado, pero él no cumple la ley porque siente compasión, compasión y perdón y posiblemente conoce la intención que tienen de incriminarlo. 
Su respuesta expresa una ingeniosa salida exculpatoria. "El que de vosotros esté sin pecado sea el primero en arrojar la piedra". De igual manera, la Torá establece la Ley en caso de celos, en el cual Dios establece un juicio conocido del agua amarga, en el cual se explicita el proceso a seguir en caso de adulterio: la fórmula establece, en resumen, que las aguas amargas que se toman ante el sacerdote dirán si la mujer es culpable o no de adulterio (Nm 5,11-29).

Como ya hemos afirmado, el fundamento principal de las leyes era el código mosaico contenido en el Pentateuco. En el Nuevo Testamento se designa como "la ley de Moisés o libro de la ley" (Mt 5,17; Rom 2,12; Lc 2,22; 24,44; Hech 28,23).

Después de la ley mosaica, las interpretaciones rabínicas contenidas en el Talmud evidenciaban su importancia en el caso. Recordemos que, el adulterio era ilícito y se configuraba como tal si un hombre o una mujer comprometidos en matrimonio asumían el coito con una pareja distinta a su prometida, que estuviera casada o comprometida ( $\mathrm{Nm} 5,11 \mathrm{ss}$ ), no obstante, la fidelidad conyugal absoluta solo pesaba sobre la mujer que en virtud del contrato matrimonial pasaba a ser propiedad del varón. Una transgresión a ello ocasionaba la pena de muerte (Dt $22,22)$ sobre el adulterio. Es decir, no se diferencia entre delito y pecado.

\subsection{Testigos y jueces}

Cabe anotar, la importancia de los testigos y los jueces. "El que sea inocente, que tire la primera piedra" (cf. Lv 24,10-16; Dt 17,2-7). Los desarrollos jurídicos encontrados establecen que el proceso judío debía normarse bajo ciertos principios, tales como la publicidad, por ello, el relato nos presenta que el juicio se desarrolla en público, frente al pueblo y en presencia de los ancianos.

De igual manera ha de hacerse por el día. Al parecer hay un rechazo a los juicios nocturnos, suponen un favoritismo a los juicios secretos, por ello también se entiende que Jesús se había presentado en la madrugada al templo, y a esta hora le presentan la mujer (Jn 8,2-3), para garantizar una defensa adecuada, que se traducía en la amplia libertad defensiva del acusado, en contraposición a Jesús que luego será aprehendido en la noche (Jn 18,1ss).

Cabe preguntarse: ¿Por qué Jesús no acusa la mujer? Ante todo debe reconocerse que el papel del juez no es acusatorio, sino defensivo, solo los testigos podían acusar: "Maestro, esta mujer ha sido sorprendida en flagrante adulterio" (Jn 8,4). Para las acusaciones y los cargos contra el acusado, sobre todo la culpabilidad castigada con la pena capital, era necesario el testimonio de dos testigos, sobre cuya probidad se apoyaba el proceso judicial judío. Si los testigos y su testimonio 
concordaban y eran fidedignos, se procedía a pronunciar la sentencia; tenían el derecho y el deber de tirar la primera piedra. En caso contrario debía abrirse investigación para comprobar la legalidad.

La respuesta de Jesús ante los acusadores sorprende; “El que esté libre de pecado arroje la primera piedra" (Jn 8,7); él encarna su papel como juez: "yo tampoco te condeno" (Jn 8,11), de modo que por el oficio conferido, no acusar ni presentar cargos contra la acusada, su papel fundamental radicaba en la defensa. Dicha defensa del juez, Jesús la sabe bien encausar, hasta ganar la absolución de la acusada evidenciada en la retirada de los acusadores.

\subsection{Jesús como juez}

Los judíos desde el año 6 d. C., estaban bajo la autoridad romana regentada por el Prefecto Procurador, encargado de la parte administrativa y judicial, con facultades para dictar sentencia incluyendo la pena de muerte. No obstante, los asuntos ordinarios, aún los judiciales, eran administrados por las autoridades judías, función realizada por el Sanedrín, tribunal supremo de los judíos; pero el llamado iusgladii como hemos dicho ya, era prerrogativa exclusiva de Roma (Francis, 2013, p. 20).

La presencia de esa institución penal, simbolizada en los ancianos y la presión ejercida sobre Jesús en busca de una respuesta llama la atención, pues Jesús no era miembro del Sanedrín, mucho menos testigo del delito que se imputaba a la mujer. Posiblemente la necesidad de destruir una supuesta pretensión mesiánica y el ambiente de tensión por el dominio jurídico y militar por parte de los romanos en una cultura teocéntrica, hacen que sea nombrado por sus interlocutores como juez, presentándose aquellos como testigos.

Ante tal pretensión, Jesús, termina mostrándose como el revelador del Padre, a través de su persona y de su palabra. El Evangelio de Juan nos muestra claramente, cuatro maneras de Jesús mostrarse como enviado de Dios, Para este caso seguimos el esquema que nos presenta Ronald Francis:

1. Jesús es el Hijo unigénito, enviado por el Padre al mundo para salvarlo (3,16-17). Solo Él lo puede revelar $(1,18)$, ya que "él está en el Padre y el Padre en él" (14,10-11). Esta mutua inmanencia es el elemento específico del modelo joánico.

2. Jesús es el Verbo encarnado, que revela a los hombres la gloria del Padre y les trae la gracia y la verdad; les da a los que creen el poder de hacerse "hijos de Dios" (1,12-13). 
3. Jesús es el Hijo del hombre, título leído sobre el trasfondo de una escatología presencial más que sobre un trasfondo apocalíptico. El Hijo del hombre, bajado del cielo $(3,13 ; 6,38.42)$ y encarnado, se presenta ya ahora como juez, que salva a quien lo acoge en la fe, pero indirectamente condena a quien lo rechaza. Como Hijo del hombre será elevado en la cruz y desde allí atraerá a todos hacia sí (12,32); reinará desde la cruz (18-19); resucitado, "subirá donde estaba antes" (cf. $6,62 ; 20,17)$.

4. Yo soy. Jesús está en el mismo plano que su Padre. Esta misma orientación -hacia el Padre y hacia los hombres- está presente en los relatos de los milagros (14,11; 15,24; cf 5,21-23); en cuanto "signos", revelan su acción salvífica respecto al hombre, respondiendo a sus expectativas existenciales más profundas (Francis, 2013, p. 28).

Por tanto, Jesús encarna al Dios fiel, justo y misericordioso. "un Dios que más allá de lo legal mira lo que hay en el corazón, mira la esencia de la persona humana que del calificativo 'esta', llamada así por los escribas y fariseos, llega a ser llamada 'mujer' por Jesús" (Flórez, 2016, p. 76).

En consecuencia, la exhortación de la perícopa encarna un carácter kerigmático, acorde con el propósito de todo el Evangelio, que fue escrito para que quienes lo lean crean en Jesús y así tengan vida en su nombre (Jn 20,31). Así pues, el "vete" expresa la absolución de la condena y al mismo tiempo evoca una misión de confianza. La mujer es enviada a dar testimonio de su fe y de la misericordia recibida. Esto hace que el lector actual del cuarto Evangelio también sienta ese llamado de Jesús a demostrar su fe mediante el testimonio, aun en circunstancias hostiles.

Los acusadores y la mujer experimentaron la misericordia de Dios. Los acusadores cayeron en la cuenta de que quien acostumbra levantar el dedo para señalar el pecado ajeno también necesita de la misericordia de Dios, pues el Señor lo ha dicho en su palabra: “No necesitan médico los que están sanos, sino los enfermos. Id, pues, y aprended lo que significa: Misericordia quiero, y no sacrificio. Porque no he venido a llamar a justos, sino a pecadores, al arrepentimiento". (Mt 9,10-13).

La misericordia de Jesús le salvó la vida a la mujer; por un lado la salva de la pena de muerte, contenida en la ley de Moisés, por otro lado, al ofrecerle el perdón de Dios que da fuerza interna para no volver a pecar, la anima a una vida nueva. Bien recoge esta expresión san Agustín: 
“Tampoco yo te condeno...”. ¿Qué quiere decir esto, Señor? ¿Tú favoreces el pecado? Ciertamente no. Escuchad lo que sigue: "Vete, y en adelante no peques más". En otras palabras, el Señor condena el pecado, pero no al pecador. De hecho si hubiera perdonado el pecado, habría dicho: Tampoco yo te condeno, vete y vive como quiera, estés segura de que yo te liberaré; por muy grandes que sean tus pecados, yo te liberaré de cualquier pena y de cualquier sufrimiento del infierno. Pero no dijo así. Este es el sentido de las palabras que dice a la mujer: "Tampoco yo te condeno...": ahora que estás tranquila a propósito de cuánto has cometido en el pasado, ten temor de cuánto podrá sucederte en el futuro. "Tampoco yo te condeno...": es decir, he destruido lo que has cometido, pero observa cuánto te he mandado, para que obtengas cuanto te he prometido" (San Agustín, Tratado 33).

La actitud de Jesús, "es hacerles ver sus miserias personales" (Cepeda et al., 2016, pp. 117-121).

\section{Conclusión}

La misericordia de Dios que sana y no juzga. El obispo san Ambrosio escribe respecto de esta perícopa:

Los escribas y los fariseos le habían llevado al Señor Jesús una adúltera con esta trampa: si la absolviese parecería no tener la ley en cuenta; si, por el contrario, la condenase, habría traicionado su misión, ya que vino para perdonar los pecados de todos. Por eso se la presentan diciendo: "Maestro, esta mujer fue sorprendida en flagrante adulterio. Ahora bien, Moisés, en la ley, nos mandó lapidar a mujeres como estas. ¿Tú que dices al respecto?".

En cuanto ellos así decían, Jesús inclinó la cabeza y se puso a escribir en el suelo con el dedo. Y como esperaban su respuesta, levantando la cabeza dice: "Quien de entre ustedes estuviese sin pecado, que sea el primero en apedrearla". ¿Habrá sentencia más divina que esta, o sea, que solo pueda punir los pecados quien estuviese sin pecado? ¿Cómo podría soportar que castigue los pecados de los otros quien defiende los suyos? ¿No se condena por sí mismo quien condena en los otros lo que él 
mismo comete? [...] Admira los divinos misterios y la clemencia de Cristo. Cuando la mujer es acusada, Jesús inclina la cabeza, pero la yergue cuando desaparece el acusador. En efecto, él no quiere condenar a nadie, sino absolverlos a todos. ¿Qué significa entonces "Vete y no vuelvas a pecar"? Esto: ya que Cristo te redimió, corrija en ti la gracia lo que la pena no podría enmendar sino solamente doblar (San Ambrosio, Carta 26).

Queremos terminar con una aplicación pastoral del texto, tratando de descubrir el sentido misericordioso que el relato presenta. Frente a la mujer y frente a sus acusadores vemos a Jesús como Señor de la misericordia y del perdón, que penetra en lo más íntimo del corazón del hombre. El contexto del pasaje es del conflicto. Vemos a un Jesús, que con su manera de actuar, cuestiona la vida de quienes le escuchan. De ahí que, los escribas y fariseos frente a la praxis de Jesús, estén al acecho y buscan la manera de tentarle y poderlo acusar de transgresor de la ley.

El hecho de que le presenten a la mujer donde lo ponen a prueba, será la ocasión para una magnífica enseñanza sobre el dinamismo del perdón y la misericordia: "reconocer el pecado, ser perdonado y perdonar a los demás. Y viceversa, así como no está autorizado para juzgar quien tiene motivos para ser juzgado, igualmente solo quien perdona puede ser perdonado por Dios" (Oñoro, 2004, p. 2).

La acusación es grave, pero resulta más grave la intencionalidad de los acusadores, no es el pecado de la mujer lo que los acerca a Jesús, sino el mismo Jesús, que se ha convertido en un personaje incómodo. Por tanto, hay que buscar una manera de "empantanarlo" para acusarlo, y luego matarlo, pues sabemos que más adelante del relato, se nos dice que lo buscaban para matarlo pero él se les escondió.

Buscan de Jesús una respuesta comprometedora. "Si Jesús aprueba el comportamiento de sus enemigos, también acepta su posición contra los pecadores; en consecuencia, tendría que ponerle fin a su praxis de misericordia y aparecer ante el pueblo como un falso maestro. Pero si Jesús no lo hace, resulta que termina desaprobando una ley inequívoca ante un hecho inequívoco, e igualmente daría motivos para ser acusado de falso maestro que aparta a la gente de la Ley de Dios y, en consecuencia, debería ser quitado de en medio del pueblo"' (Oñoro, 2004, p. 2).

El gesto silencioso de Jesús, es un llamado a la meditación, al discernimiento. Quizás, sea la primera respuesta que dio, cualquier decisión debe ser tomada con responsabilidad, pues está en juego la salvación o condena del ser humano. Tal vez sea una manera pedagógica de invitarlos a reflexionar como pueblo, pues están reunidos todos los estamentos de Israel, están los letrados, los que interpretan la ley y el pueblo, los ancianos. 
El silencio de Jesús, puede que sea la toma de consciencia de que el pueblo también ha sido infiel a Dios y de ello, da muestra el matrimonio de Oseas, con la prostituta (Os 2,14). También lo cuenta Ezequiel (8,7-18); sin embargo la respuesta de Dios ha sido la misericordia (Lc 15,1ss; Ez 36,24-26). De ahí que, con el silencio, Jesús podría estar recordando a Jeremías 17,13 que escribe: "Los que se apartan de ti, en la tierra serán escritos, por haber abandonado el manantial de aguas vivas, Yahveh". De ser así, ¿Jesús le estaría recordando a sus adversarios que son infieles a Dios y merecen ser escritos en el polvo y extinguidos? (Oñoro, 2004, p. 2).

De cualquier forma, cuando se es duro de cerviz, se pierde la paciencia y la dimensión de misericordia, por ello, en muchas ocasiones, cabe recordar e invitar al autoexamen. "Quien esté libre de pecado, que arroje la piedra". Con tal sentencia, Jesús, exhorta a examinar la vida interior en relación con mi propio pecado; invita a revisar la ley, que no puede seguir siendo el paradigma para juzgar a todos bajo el mismo peso y cuestiona la vida personal en relación con el pecado personal y abandonarlo buscando un cambio de vida.

El nuevo silencio, introducido en el relato es la toma de consciencia, de mis propios actos ante Dios y la comunidad. Un hombre sensato, cae en la cuenta de que las palabras de Jesús, transforman el corazón, por ello ya no lanza piedras, se siente transformado también, por aquel hombre que no lo juzga $(J n 8,15)$ y por el contrario le asigna una nueva tarea, la conversión.

Finalmente, vemos que Jesús, absuelve, pero no aprueba el pecado. Le habla pidiéndole que se abstenga del comportamiento adultero que la expuso a la muerte y le ofrece la posibilidad de rehacer la vida. De modo que, al final del relato nos queda la enseñanza, de que quien levanta el dedo para señalar el pecado del otro, necesita también misericordia y experimentar el perdón de Dios para no atentar contra el hermano. El pecado no necesita ser castigado sino redimido y por esa redención, surge la toma de consciencia que nos hace abandonarlo definitivamente.

\section{Referencias}

Brown, R. E., Fitzmayer J. A., y Murfhy R. E. (1972). Comentario bíblico de san Jerónimo. Tomo IV. Madrid, España: Ediciones Cristiandad.

Brown, R. E. (2010). Nuevo comentario bíblico de San Jerónimo. NT. Navarra, España: Ediciones Cristiandad.

Cardona R., H. (2016). La compasión en la Biblia. Pistas para el año de la misericordia. Bogotá D. C., Colombia: Litocolor litografía. 
Castro, S. (2001). Evangelio de Juan: comprensión exegético-existencial. Madrid, España: Desclée de Brouwer.

Cepeda, A., García, R., Garzón, M., Rojas, I., y Segura, W. (2016). Misericordiosos como el Padre. Navarra, España: Verbo Divino.

Flórez P., H. (2016). Aproximación a la justicia transicional en Colombia a la luz de Juan 7,53-8,11. Corporación Universitaria Minuto de Dios, Bogotá D. C., Colombia.

Francis B., R. F. (2013). El concepto de persona y la imputabilidad penal en el CIC 1983 (CC. 1321-1330) (tesis de doctorado). Pontificia Universidad Javeriana, Bogotá D. C., Colombia.

Metzger, B. M. (2006). Un comentario textual al nuevo testamento griego. Brasil: Sociedades Bíblicas Unidas.

Oñoro, F. (2004). Estudio bíblico de apoyo para la Lectio Divina del Evangelio: quinto domingo de cuaresma, Ciclo C. Bogotá D. C., Colombia: CEBIPAL.

Rajna, G. S. (2000). L'abecedaire du Judaïsme. París, Francia: Flammarion.

Sánchez, W. G. (2010). Jesús y la mujer adúltera: análisis exegético-teológico. Franciscanum, tomo 52.

Santa Teresa de Jesús (2000). Obras Completas. Madrid, España: Editorial de Espiritualidad.

Schnackenburg, R. (1980). El evangelio según San Juan: II versión y comentario. Barcelona, España: Herder.

Sarasa, G. (2004). Para ser hijos de Dios: un estudio exegético de Juan. Bogotá D. C., Colombia: Editorial Javeriana. 